\title{
LENGTH-BASED STOCK ASSESSMENT OF OREOCHROMIS MOSSAMBICUS AND OREOCHROMIS NILOTICUS (ACTINOPTERYGII: PERCIFORMES: CICHLIDAE) IN MULTI-MESH GILLNET FISHERIES IN RESERVOIRS OF SRI LANKA
}

\author{
Upali S. AMARASINGHE ${ }^{*}$, R.P. Prabath K. JAYASINGHE ${ }^{1,2}$, and Jacques MOREAU 3 \\ ${ }^{1}$ Department of Zoology and Environmental Management, University of Kelaniya, Sri Lanka \\ ${ }_{2}^{2}$ (present affiliation) Marine Biological Resources Division, National Aquatic Resources Research and Development \\ Agency, Crow Island, Colombo 15, Sri Lanka \\ ${ }^{3}$ Department of Inland Fisheries, INP/ENSAT, Auzeville-Tolosane, France
}

\begin{abstract}
Amarasinghe U.S., Jayasinghe R.P.P.K., Moreau J. 2017. Length-based stock assessment of Oreochromis mossambicus and Oreochromis niloticus (Actinopterygii: Perciformes: Cichlidae) in multi-mesh gillnet fisheries in reservoirs of Sri Lanka. Acta Ichthyol. Piscat. 47 (3): 265-277.
\end{abstract}

\begin{abstract}
Background. Gillnets of mesh sizes $(6.9$ to $12.7 \mathrm{~cm}$ ) are used in individual boats in Sri Lankan reservoirs targeting exotic cichlid species, Oreochromis mossambicus (Peters, 1852) and Oreochromis niloticus (Linnaeus, 1758), which dominate the fisheries. The mesh composition of gillnets varies from boat to boat and from season to season making catch samples in individual boats are under the influence of different selectivity patterns. As such, the conventional procedure of correcting length frequency samples using the overall mean selectivity pattern in the fishery is not precise in estimating growth parameters. The presently reported study aimed at assessing cichlid stocks in three tropical reservoirs accounting for gillnet selectivity of individual sampled boats.

Material and methods. Length frequency data obtained from each boat were corrected for the combined selectivity of the fleet of gillnets of different mesh sizes used in the boat during the sampling occasion. For predicting optimal fishing strategies using a yield-per-recruit approach, probabilities of capture determined from the array of fishing mortality in the length-structured virtual population analysis was incorporated.

Results. Length frequency data corrected for overall gillnet selectivity in sampled boats gave reliable estimates of von Bertalanffy growth parameters. Based on these estimates, mortality parameters were determined and the overall gear selection pattern was deduced from the array of fishing mortality in the length-structured virtual population analysis. Optimal fishing strategies were determined incorporating overall probabilities of capture in the relative yield-per-recruit $\left(Y^{\prime} \times R^{-1}\right)$ analysis.

Conclusion. The overall gillnet selection pattern of a sampled boat offers a methodology for reliable estimation of growth parameters. Although both cichlid species are caught in gillnets simultaneously, $Y^{\prime} \times R^{-1}$ analyses predicted increase of exploitation rate for one species while its decrease for the other species perhaps due to influence of other factors such as fish behaviour and fishers' choice of specific areas for fishing. This analysis provides a methodology of a more precise length-based stock assessment in future research.
\end{abstract}

Keywords: ELEFAN, FiSAT, gillnet selectivity, inland fisheries, tropical reservoirs

\section{INTRODUCTION}

Reservoir construction has been worldwide and the cumulative extent of reservoirs in the world exceeds $400000 \mathrm{~km}^{2}$ (Avakyan and Iakovleva 1998), and those in the tropical belt support productive fisheries (Oglesby 1985, Fernando and Holčík 1991, Amarasinghe and De Silva 2015). Reservoir fisheries possess unique characteristics, compared to various other sectors in the fishing industry. For example, the majority of reservoir fisheries are artisanal (Welcomme 2001), and in Sri Lanka, fishing methods in reservoirs are restricted to gillnets. Presence of impediments for fishing such as submerged decaying tree stumps also prevents use of any other type of fishing gear other than passive gear such as gillnets (Pauly 1984, De Silva 1996). Furthermore, according to inland fisheries regulations in Sri Lanka, use of any kind of towing or surrounding nets in reservoirs is forbidden. Despite the availability of simple empirical yield predictive models for tropical lake and reservoir fisheries (Anonymous 1995), stock assessment methodologies have been recognized as possible means for determining optimal fishing strategies (Pauly 1984, De Silva et al. 1991, Cowx 1996). However,

" Correspondence: Professor U.S. Amarasinghe, Department of Zoology and Environmental Management, University of Kelaniya, Kelaniya 11600, Sri Lanka, phone +94 11 2914479, fax: +94 11 2911916, e-mail: (USA) zoousa@kln.ac.lk, (RPPKJ) prabath_jayasinghe@yahoo.com, (JM) jacques.moreau@ensat.fr. 
gillnets are highly selective from which catch samples are often non-representative of the population. Hence, the majority of length-based stock assessment methodologies (Pauly and Morgan 1987), which are proven to be suitable for assessing tropical fish stocks, are not readily applicable for assessment of reservoir fisheries.

The majority of length-based stock assessment methodologies (Gayanilo et al. 2005) rely on the correction of length frequency data, which are sequentially arranged with time using a mean selection curve. However, in the majority of reservoir fisheries, such as those in Sri Lanka where multi-mesh gillnets are used, fishers often remove fish specimens caught in gillnets and land them as a mixture of catches from individual gillnets (Amarasinghe and Weerakoon 2009). Also composition of mesh sizes of gillnets, used by fishers also vary from season to season in the majority of reservoir fisheries in the tropics, due to the seasonality of the catchability of target species (Amarasinghe and De Silva 2015, Jayasinghe et al. 2017).

When the influence of selection characteristics of gillnets on size composition of the catches is reviewed, a uniform pattern of capture by gillnets is not evident. Fonseca et al. (2005), through experimental gillnet fishing off the western coast of Portugal, have shown that management of multi-species fisheries, based only on mesh size would be difficult because optimal mesh size varies considerably among the target species. Fonseca et al. (2005) also stated that in addition to mesh size, a number of technical characteristics related to gear construction such as hanging ratio have some influences on the catch size distribution. Colour of twine (Tweddle and Bodington 1988) and twine thickness (Holst et al. 2002) are other technical characteristics of gillnets which influence their selectivity. Further, presence of body projections such as teeth or spines, facilitate significant proportion of fish being entangled in gillnets (Sparre and Venema 1998). Also higher swimming activity of fish is another biological characteristic which can result in high encountering probability (Rudstam et al. 1984). Gray et al. (2005) on the other hand, have concluded from the results of experimental gillnet fishing that there were no significant differences between different hanging ratios or twine diameters on the size composition of catches and by-catches, but lowering the fishing height of the floatlines of gillnets significantly reduced total by-catch. These warrant the need of an objective approach for correcting gillnet catch size distribution.

Length-based stock assessment methodologies employed for the analysis of length frequency data from gillnet fisheries, often assume that size distribution of fish in the catches of a gang of mesh sizes represents that of the population. For example, Al-Hosni and Siddeek (1999), who utilized length frequency samples of Scomberomorus commerson (Lacepède, 1800) from gillnet and line fisheries, as majority of fishes fall within 48-147 cm fork length (FL) from the overall range of 24-179 cm FL, growth parameters were estimated without incorporating correction factors for gillnet selectivity. Amarasinghe et al. (1989), Amarasinghe and De Silva
(1992) and Amarasinghe (2002) have also assumed that in the multi-mesh gillnet fisheries for Oreochromis mossambicus (Peters, 1852) and Oreochromis niloticus (Linnaeus, 1758) in Sri Lankan reservoirs, selection effects of individual mesh sizes were negligible over a wide range of size classes. Moreau et al. (2008) also adopted a similar approach for investigating population dynamics of commercially important fish species in four Asian reservoirs. However, Athukorala and Amarasinghe (2010) have analysed length frequency data of $O$. mossambicus and $O$. niloticus in two irrigation reservoirs of Sri Lanka, corrected for mean selection patterns as determined from the array of fishing mortality resulted from length based virtual population analysis.

The reservoir fishery of Sri Lanka is essentially a multi-mesh gillnet fishery targeting Oreochromis mossambicus and O. niloticus (see De Silva 1988, Amarasinghe and Weerakoon 2009). Due to the seasonal variations in the size structure of the stocks of these target species, reservoir fishers are compelled to use different mesh compositions of gillnets during different seasons (Pet et al. 1995, Sricharoendham et al. 2008). As such, sample bias due to the effect of gillnet selectivity needs to be treated individually in length-based stock assessment procedures. Towards this goal, an attempt was made in the presently reported study, to assess the fisheries of commercially important fish species in three reservoirs of Sri Lanka using length-based stock assessment methodologies.

\section{MATERIALS AND METHODS}

Studies were carried out in three Sri Lankan reservoirs viz. Minneriya, Udawalawe, and Victoria, locations of which are shown in Jayasinghe et al. (2017). Some morphometric characteristics of the three reservoirs are given in Table 1. The main fishing craft is non-motorized, fibre-glass out-rigger canoe and the gear is gillnet. Fishers use fleets of gill nets of stretched mesh sizes ranging from 6.9 to $12.7 \mathrm{~cm}$ having a hanging ratio of 0.5 . They are mostly bottom set gillnets and the height and length of each net are approximately $2 \mathrm{~m}$ and $50 \mathrm{~m}$, respectively.

Length frequency data of two cichlid fish species namely Oreochromis mossambicus and $O$. niloticus, which are commercially important in all three reservoir fisheries, contributing to over $70 \%$ of the landings (Sricharoendham et al. 2008), were collected from the commercial gillnet catches of randomly selected boats approximately at bimonthly intervals from August 1998 to July 2000. Data collection was essentially done during the short time period available between landing and selling of fish to vendors. The collected length frequency data of two cichlid species were of two categories; one is that when the boats were landed, the composition of gillnet mesh sizes could be observed during the limited time availability, length frequency data of fish were recorded separately (hereafter $\mathrm{mLF}$ ), and the other is that length frequency data recorded from the boats where mesh composition of gillnets was not known (hereafter nLF). Using the approach presented by Jayasinghe et al. (2017), the overall gillnet selection 
Table 1 Principal morphometric and edaphic parameters of three reservoirs studied (adopted from Silva and Gamlath 2000)

\begin{tabular}{lccc}
\hline \multirow{2}{*}{\multicolumn{1}{c}{ Parameter }} & \multicolumn{2}{c}{ Reservoir and its coordinates } \\
\cline { 2 - 4 } & Minneriya & Udawalawe & Victoria \\
& $8^{\circ} 02^{\prime} \mathrm{N}, 80^{\circ} 53^{\prime} \mathrm{E}$ & $6^{\circ} 27^{\prime} \mathrm{N}, 80^{\circ} 50^{\prime} \mathrm{E}$ & $7^{\circ} 13^{\prime} \mathrm{N}, 80^{\circ} 47^{\prime} \mathrm{E}$ \\
\hline Altitude above mean sea level $[\mathrm{m}]$ & 96 & 80 & 438 \\
Area [ha] & 2551 & 3408 & 2270 \\
Mean depth $[\mathrm{m}]$ & 5.8 & 7.9 & 30.5 \\
Catchment $\left[\mathrm{km}^{2}\right]$ & 249 & 1164 & 1891 \\
Volume $[\mathrm{MCM}]$ & 135 & 268 & 783 \\
Flushing rate $[$ years $]$ & 0.766 & 0.631 & 1.018 \\
Mean annual temperature $\left[{ }^{\circ} \mathrm{C}\right]$ & 28 & 28 & 26 \\
pH & $7.32-8.35$ & $7.33-8.58$ & $6.7-8.37$ \\
Conductivity $\left[\mu \mathrm{S} \mathrm{cm}^{-1}\right]$ & $98-213$ & $102-134$ & $66-93$ \\
\hline
\end{tabular}

$\mathrm{MCM}=$ million cubic metres.

pattern of a fleet of gillnets of various mesh sizes operated in a sampled boat was estimated as follows:

$$
P_{t}=\left(\sum\left(n_{i} P_{i j}\right)\right) \times\left[\max \left(\sum\left(n_{i} P_{i j}\right)\right)\right]^{-1}
$$

where, $P_{t}$ is the overall probability of capture of $j^{\text {th }}$ length class of fish, $n_{i}$ is the number of net pieces of $i^{t h}$ mesh gillnet, $P_{i j}$ is the probability of capture in $i^{\text {th }}$ mesh gillnet in $j^{\text {th }}$ length class as estimated from Baranov-Holt method (Gayanilo et al. 2005), and $\max \left(\sum\left(n_{i} P_{i j}\right)\right)$ is the maximum value of $\left(\sum\left(n_{i} P_{i j}\right)\right)$ estimated. In correcting length frequencies for probabilities of capture, probabilities less than 0.01 were not used in order to prevent possible over-estimation of corrected frequencies (Gayanilo and Pauly 1997).

A time series length frequency data file, corrected for overall gillnet selection from the equation (1) above, was constructed for the boats with mLF using FiSAT software (Gayanilo et al. 2005). Then the parameters of von Bertalanffy growth function (VBGF) were estimated using ELEFAN technique implemented in the same software. Growth performance indices $\left(\sigma^{\prime}\right)$ of Oreochromis mossambicus and $O$. niloticus in the three reservoirs were also estimated using $\varnothing^{\prime}=2 \log _{10} \mathrm{SL}_{\infty}+\log _{10} K$ (Pauly and Munro 1984, Moreau et al. 1986), where $\mathrm{SL}_{\infty}$ is asymptotic standard length and $K$ is growth constant. As the asymptotic length in the presently reported study was determined from total length $\left(\mathrm{TL}_{\infty}\right)$, for comparison with those recorded as $\mathrm{SL}_{\infty}$ from feral populations elsewhere were also gleaned from FishBase (Froese and Pauly 2017) elsewhere, $\mathrm{TL}_{\infty}$ values were converted to $\mathrm{SL}_{\infty}$ assuming $\mathrm{SL}_{\infty} \approx 0.8 \times$ $\mathrm{TL}_{\infty}$ (De Silva and Senaratne 1988, Kosai et al. 2014).

The monthly mLF and nLF collected from all the sampled boats were pooled and raised to the total catch that was estimated from a parallel study (Sricharoendham et al. 2008). With the estimated asymptotic length and growth constant of each stock, natural mortality $(M)$ was estimated from Pauly's (1980) function, $\log _{10} M=-0.0066$ - 0.279 $\log _{10} \mathrm{TL}_{\infty}+0.6543 \log _{10} K+0.4634 \log _{10}$ $T$. Here, $T$ is the mean habitat temperature. In Minneriya and Udawalawe reservoirs, mean habitat temperature was $28^{\circ} \mathrm{C}$ whereas it was $26^{\circ} \mathrm{C}$ in Victoria reservoir (Table 1 ).
Length-structured virtual population analysis (VPA) was carried out to reconstruct the population from size-wise total catch data in the length frequency samples raised to the total catch (Gayanilo and Pauly 1997, Gayanilo et al. 2005). Here, input parameters used were asymptotic length $\left(L_{\infty}\right)$, growth constant $(K)$ and $M$ estimated above, and terminal fishing mortality (i.e., fishing mortality of the oldest size class) which was set very low $(<0.2)$ due to the reason that selection of the largest length classes in the fleet of gillnets would be small. Fishing mortality of each length class ( $F$-array) estimated from VPA was used to construct the probability of capture in each length class as follows (Sparre and Venema 1998):

$$
P_{i}=F_{i} \times F_{\max }^{-1}
$$

where $P_{i}$ is the probability of capture at $i^{\text {th }}$ length class, $F_{i}$ is the fishing mortality at $i^{\text {th }}$ length class, and $F_{\text {max }}$ is the maximum fishing mortality in the $F$-array. From a plot of $P_{i}$ against length, the length at $50 \%$ probability of capture (i.e., length at first capture; $L_{c}$ ) was determined.

Total mortality $(Z)$ was estimated from lengthconverted catch curve method (Pauly 1983). Here, selection of data points in the catch curve for linear regression was based on the range of relative age which represented approximately a plateau range of $P_{i}$ in the fully selected phase of the stock. Fishing mortality $(F)$ was estimated by deducting $M$ from $Z$ and exploitation rate $(E$ $\left.=F \times Z^{-1}\right)$ was computed to assess the status of the fishery.

Finally, relative yield-per-recruit $\left(Y^{\prime} \times R^{-1}\right)$ analysis was performed for each fish stock incorporating probabilities of capture (Pauly and Soriano 1986) as determined from the $F$-array of VPA. The optimum length at first capture $\left(L_{\text {c-opt }}\right)$ and optimal $E\left(E_{\max }\right)$ were determined. The sub-optimal level of exploitation rate, $E_{0.1}$, which was analogous to $F_{0.1}$ (the fishing mortality rate at which the slope of the yield per recruit curve as a function of fishing mortality is $10 \%$ of its value at the origin; Gulland and Boerema 1973, Caddy and Mahon 1995) was treated as the reference point for management of the fisheries in the presently reported study. 


\section{RESULTS}

The overall distributions of $\mathrm{mLF}$ and $\mathrm{nLF}$ of Oreochromis mossambicus and $O$. niloticus raised to the total catch in three reservoirs studied (Fig. 1) showed unimodal distributions justifying the need for analysing length frequency data with appropriate corrections for gillnet selectivity. Asymptotic total length $\left(L_{\infty}\right)$ and $K$ of both cichlid species estimated from the boats with $\mathrm{mLF}$, which were corrected for overall gillnet selection for the fleet of mesh sizes showed inverse trends in the three reservoirs (Table 2). Growth performance indices ( $\left.\varnothing^{\prime}\right)$ estimated for $O$. mossambicus and $O$. niloticus in three reservoirs fall within the ranges of those recorded elsewhere (Table 3 ). Furthermore, growth parameters estimated in the presently reported study superimposed in the 'auximetric plots' of In $L_{\infty}$ against $\ln K$ (Pauly 1998) representing 'growth space' of two cichlid species in feral populations as recorded in www.fishbase.org (Fig. 2) also indicated that estimated $L_{\infty}$ and $K$ were biologically reasonable.

From the graphical representations of VPA (Fig. 3), it can be seen that in the exploitation phases of all six stocks, $F$ values were not consistent. Accordingly, the size ranges of fish stocks which represented more or less consistent probabilities of capture (Fig. 4), were picked up
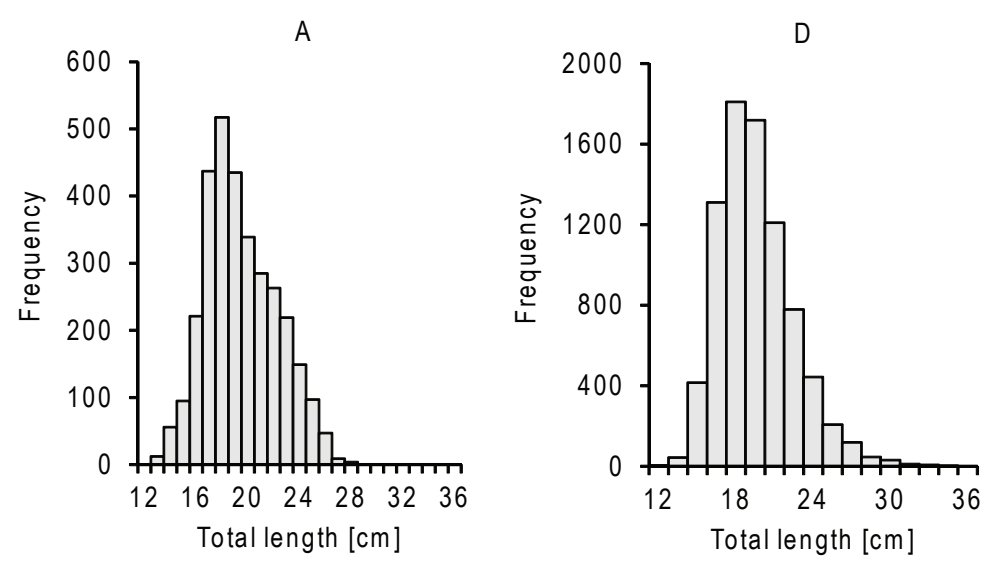

B

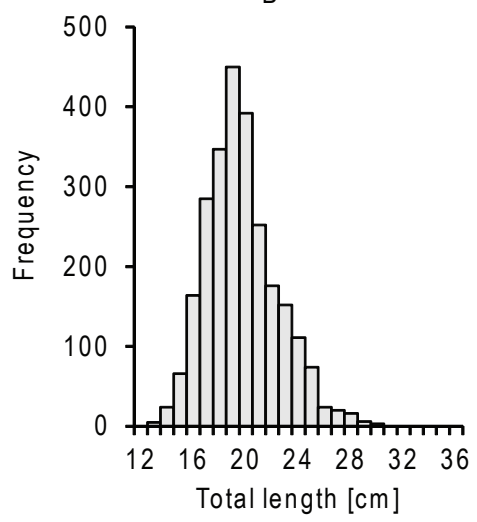

$E$

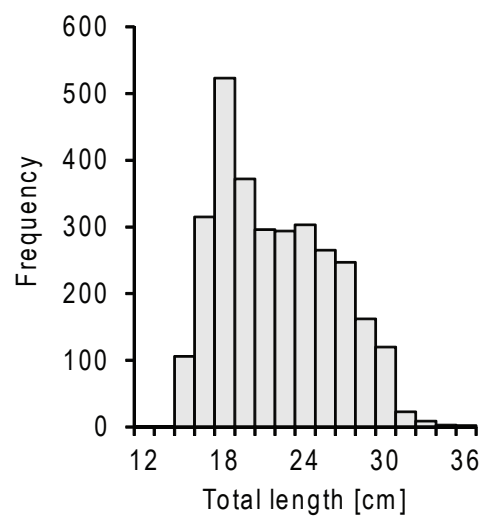

C

$\mathrm{F}$
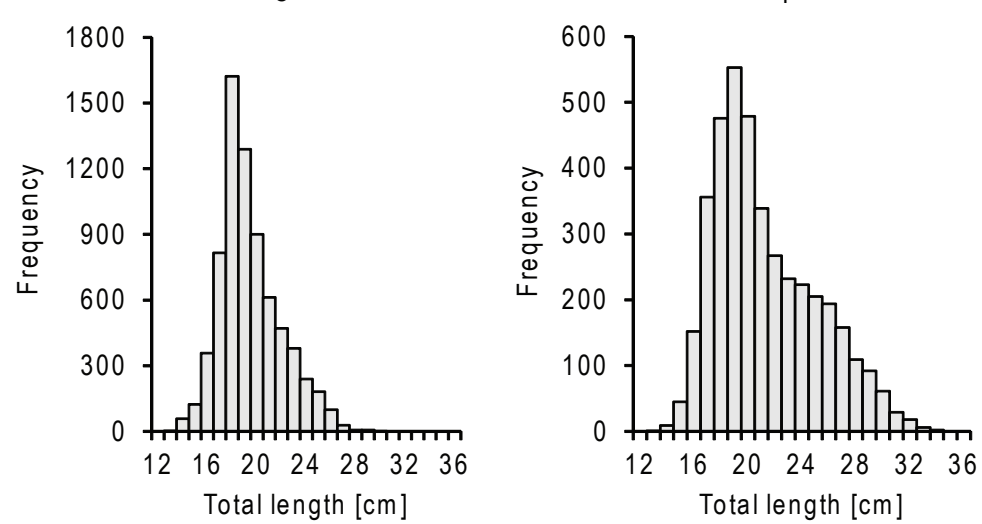

Fig. 1. Length frequency distributions of Oreochromis mossambicus in (A) Minneriya, (B) Udawalawe, and (C) Victoria; and Oreochromis niloticus in (D) Minneriya, (E) Udawalawe, and (F) Victoria 
Table 2

Estimated von Bertalanffy growth parameters of Oreochromis mossambicus and Oreochromis niloticus in three reservoirs of Sri Lanka

\begin{tabular}{lccc}
\hline \multicolumn{1}{c}{ Species/Parameter } & & Reservoir & Victoria \\
\cline { 2 - 4 } & Minneriya & Udawalawe & 43.2 \\
\hline O. mossambicus & & & 0.29 \\
Asymptotic total length [cm] & 40.2 & 42.4 & 44.3 \\
Growth constant [year ${ }^{-1}$ ] & 0.42 & 0.31 & 0.39 \\
\hline O. niloticus & & & 48.7 \\
Asymptotic total length [cm] & 47.4 & 0.29 & \\
Growth constant [year ${ }^{-1}$ ] & 0.32 & & \\
\hline
\end{tabular}

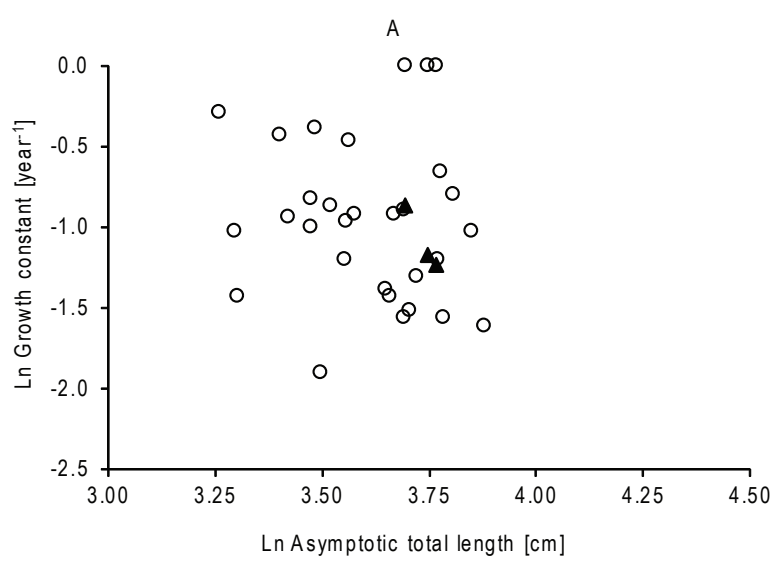

B

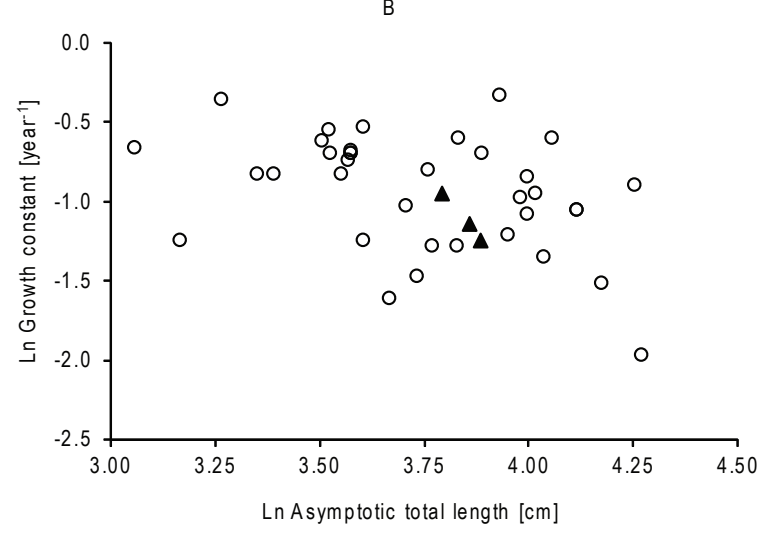

Fig. 2. Growth space of feral populations of(A) Oreochromis mossambicus and (B) Oreochromis niloticus; dark triangles are data from the presently reported study; open circles are data from other sources (Froese and Pauly 2017)

for estimating $Z$ from length-converted catch curves (Fig. 5). The estimated $Z, M$, and $F$ of the two cichlid species in three reservoirs (Table 4) indicate that except Oreochromis niloticus in Udawalawe reservoir, all populations had considerably high mortalities. The striking point here is that in Udawalawe reservoir where probabilities of capture of $O$. niloticus were peaked only at higher length classes $(>29.0 \mathrm{~cm})$, the lowest $Z$ was registered.

Relative yield-per-recruit $\left(Y^{\prime} \times R^{-1}\right)$ values and relative biomass-per-recruit $\left(B^{\prime} \times R\right)$ values as the functions of $E$
Growth performance index $\left(\varnothing^{\prime}\right)$ values of Oreochromis mossambicus and Oreochromis niloticus in three reservoirs of Sri Lanka related to respective published data from other locations

\begin{tabular}{lc}
\hline \multicolumn{1}{c}{ Species/Location } & $\varnothing^{\prime}$ \\
\hline O. mossambicus & \\
Minneriya & 2.64 \\
Udawalawe & 2.55 \\
Victoria & 2.54 \\
Various parts of the world & $2.02-2.80$ \\
O. niloticus & \\
Minneriya & 2.66 \\
Udawalawe & 2.64 \\
Victoria & 2.69 \\
Various parts of the world & $2.01-3.11$ \\
\hline
\end{tabular}

Data from various parts of the world were taken from Froese and Pauly (2017); ø' $=2 \log _{10} \mathrm{SL}_{\infty}+\log _{10} K$; Pauly and Munro 1984, Moreau et al. 1986; the asymptotic total length $\mathrm{TL}_{\infty}$ in $\mathrm{cm}$ was converted to asymptotic standard length in $\mathrm{cm}\left(\mathrm{SL}_{\infty}\right)$ using $\mathrm{SL}_{\infty} \approx$ $0.8 \times \mathrm{TL}_{\infty}$

(Fig. 6) of the two cichlids in three reservoirs at the current sizes of first capture (i.e., $L_{\mathrm{c}}$ or length at $50 \%$ probability of capture determined from Fig. 4) show that in all six stocks, the optimal $E$ at the present $L_{\mathrm{c}}$ was much greater than $E$ corresponding to $B^{\prime} \times R$ of 0.5 .

The present $L_{\mathrm{c}}$ of all populations except Oreochromis niloticus in Minneriya reservoir were higher than $L_{\text {c-opt }}$ (Table 4) showing that at the present level of $E$, size of first capture is within the safe zone in all cichlid populations except $O$. niloticus in Minneriya. Present levels of $E$ also lower than the optimal levels of exploitation $\left(E_{\text {opt }}\right)$ in all populations except for $O$. niloticus in Minneriya reservoir, as predicted from $Y^{\prime} \times R^{-1}$ analysis (Table 4). Optimal gillnet mesh sizes for $L_{\mathrm{c}-\mathrm{opt}}$, estimated on the basis of the relations between gillnet mesh size and optimal length of gillnet selection for both cichlid species (Jayasinghe et al. 2017), indicate that the stretched mesh size of $8.5 \mathrm{~cm}$ is generally appropriate for the fisheries of the two cichlids in all three reservoirs. According to the present analysis, O. mossambicus in Udawalawe and Victoria reservoirs had higher $E$ than $E_{0.1}$ (Fig. 6, Table 5). For O. niloticus 
stocks, higher $E$ than $E_{0.1}$ was found in Minneriya whereas in other two reservoirs, present $E$ was lower than $E_{0,1}$ (Fig. 6 , Table 5).

\section{DISCUSSION}

In many reservoir fisheries in the tropics, due to the presence of impediments for fishing such as submerged tree stumps and rocks, use of fishing gear other than passive fishing gear such as gillnets is virtually impossible (Welcomme 2001, Amarasinghe and De Silva 2015). Consequently, employing length-based stock assessment for their fisheries is often problematic. As many reservoir fisheries in Asia are the affordable sources of animal protein for rural communities (De Silva and Amarasinghe 2009), their effective management is imperative in terms of development of rural economy. Length-based stock assessment methodologies (Gayanilo and Pauly 1997) are useful for defining reference points for fisheries management (Caddy and Mahon 1995) especially in tropical waters. The present analysis provided an effective means of addressing the issue of estimation of growth and mortality parameters more accurately for length-based stock assessment from the datasets affected by multimesh gillnet selection.
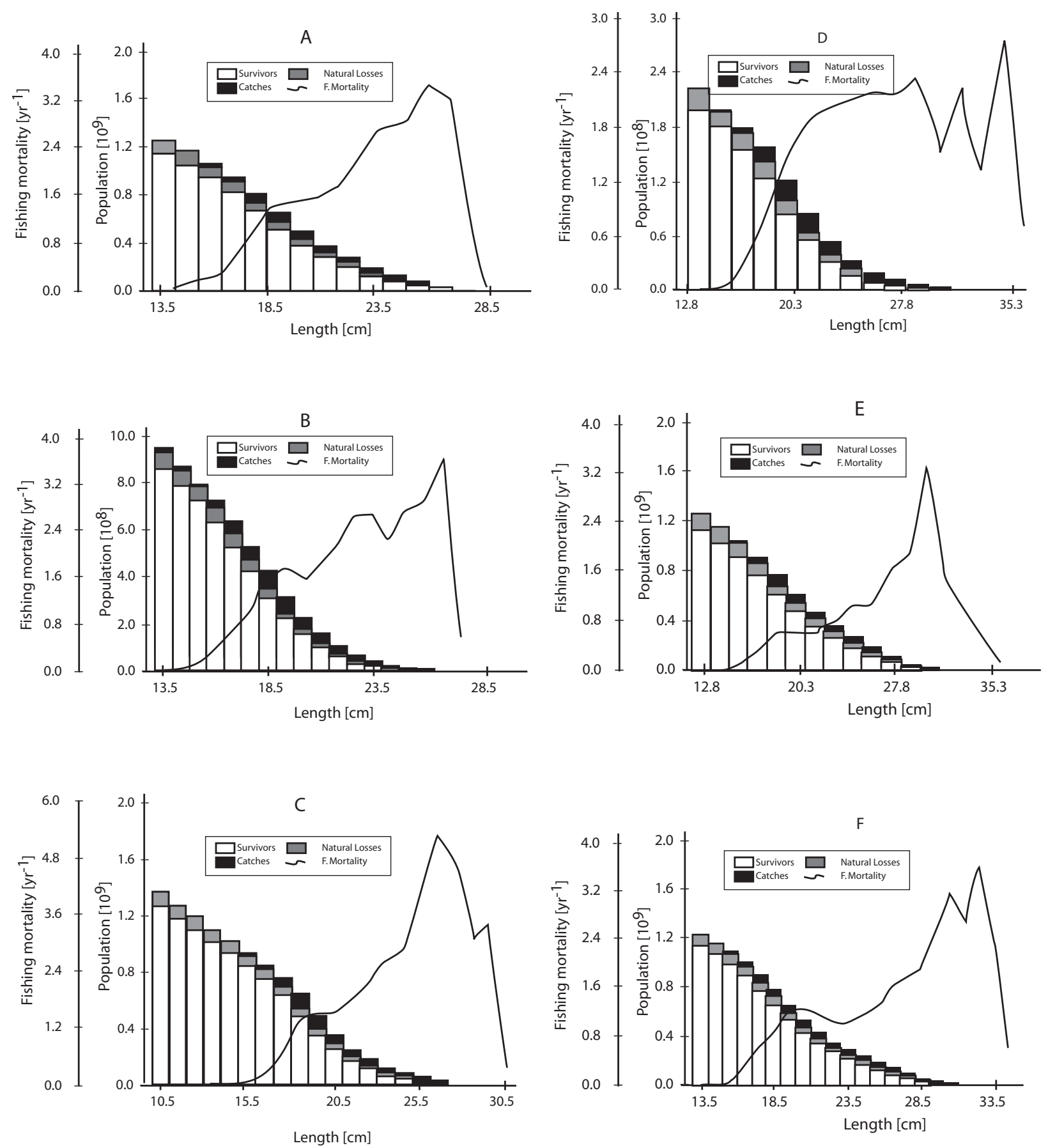

Fig. 3. Length-structured VPA of Oreochromis mossambicus in (A) Minneriya, (B) Udawalawe, and (C) Victoria; and Oreochromis niloticus in (D) Minneriya, (E) Udawalawe, and (F) Victoria; F.Mortality = fishing mortality 
It is straightforward to account for sigmoid selection ogives such as trawl selection curves in length-based stock assessment, especially due to the availability of simple approaches. For example, construction of selection patterns is possible from detailed analysis of ascending parts of catch curves, as implemented in FiSAT software
(Gayanilo et al. 2005). Also, when the gear types used in a particular fishery is consistent, determination of selection patterns is also relatively simple because $F$-array resulted from VPA can be used for construction of overall selection patterns (Sparre and Venema 1998), and the overall gillnet selection from a fleet of mesh sizes can be quantified
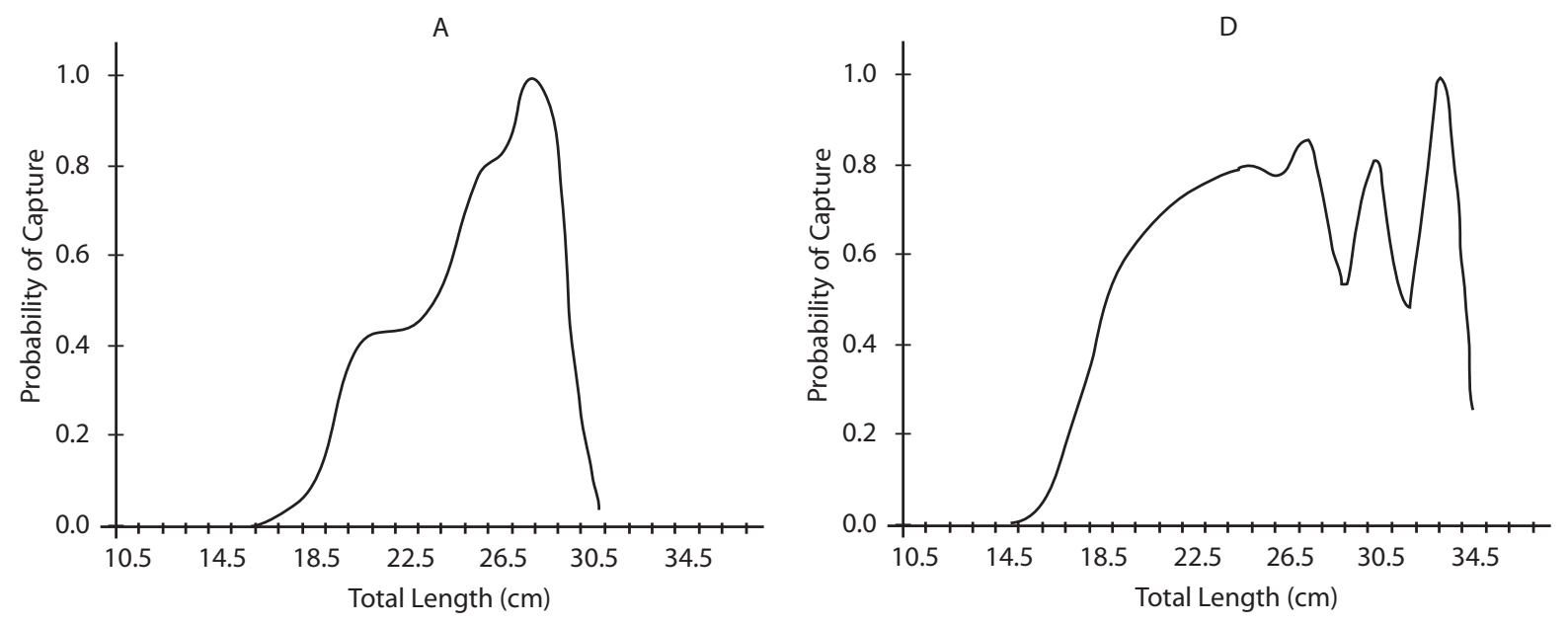

B
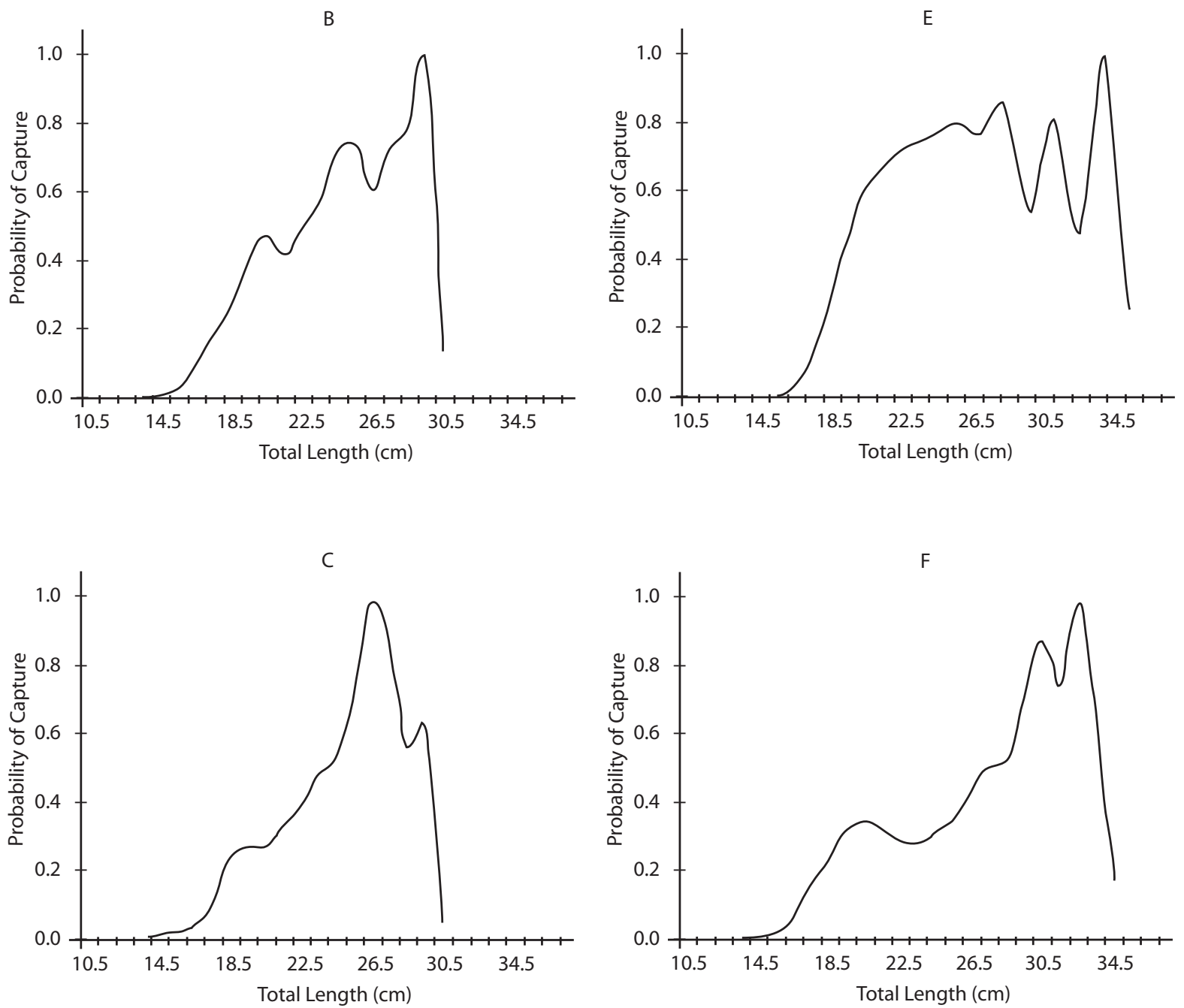

Fig. 4. Probabilities of capture of Oreochromis mossambicus in (A) Minneriya, (B) Udawalawe, and (C) Victoria; and Oreochromis niloticus in (D) Minneriya, (E) Udawalawe, and (F) Victoria 

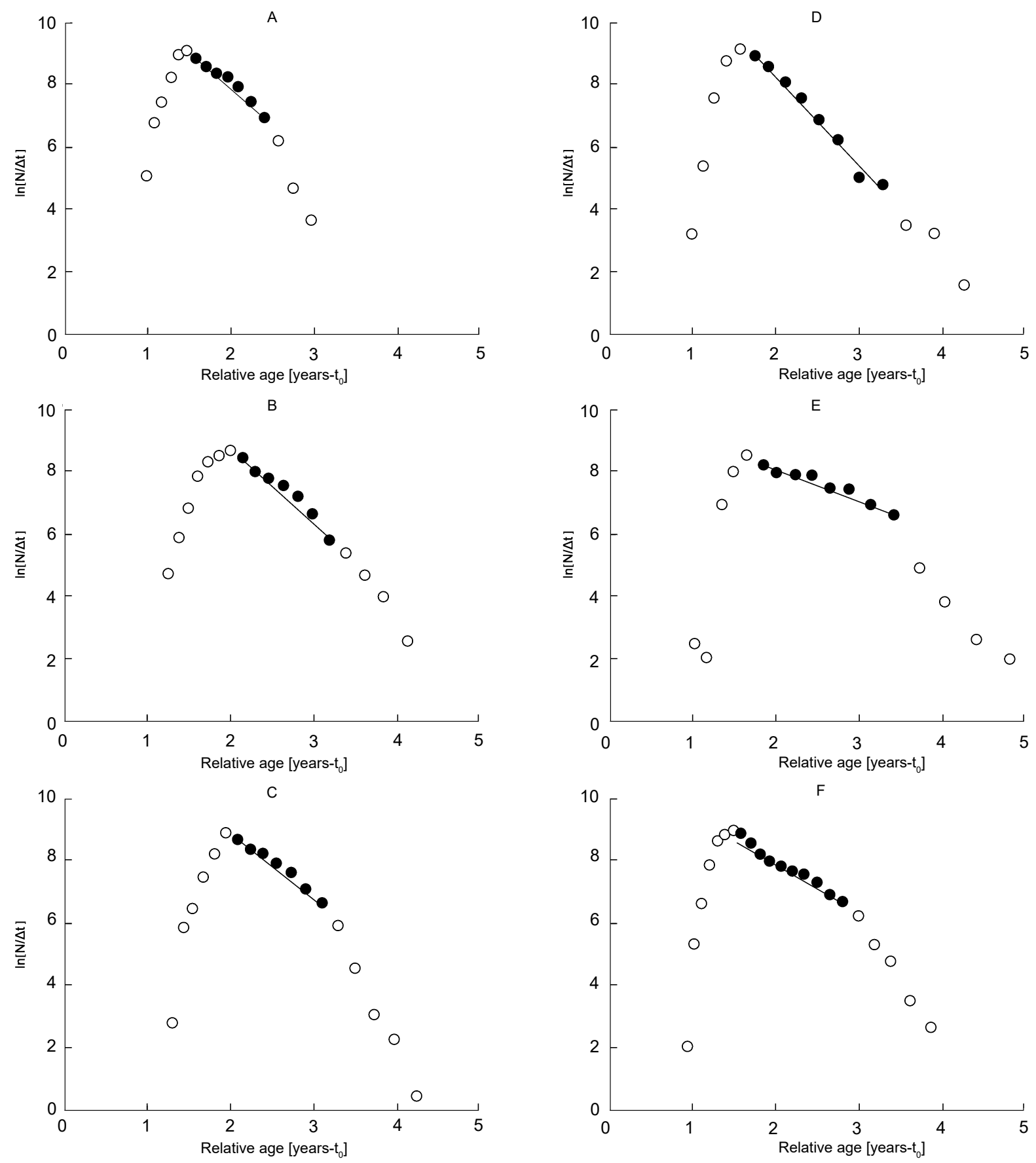

Fig. 5. Length-converted catch curves of Oreochromis mossambicus in (A) Minneriya, (B) Udawalawe, and (C) Victoria; and Oreochromis niloticus in (D) Minneriya, (E) Udawalawe, and (F) Victoria; dark circles were used and open circles were not used for regression

Table 4

Mortality values of Oreochromis mossambicus and Oreochromis niloticus in three reservoirs of Sri Lanka

\begin{tabular}{|c|c|c|c|c|c|c|}
\hline \multirow{3}{*}{ Mortality parameter } & \multicolumn{6}{|c|}{ Reservoir } \\
\hline & \multicolumn{2}{|c|}{ Minneriya } & \multicolumn{2}{|c|}{ Udawalawe } & \multicolumn{2}{|c|}{ Victoria } \\
\hline & $\mathrm{Om}$ & On & $\mathrm{Om}$ & On & $\mathrm{Om}$ & On \\
\hline $\mathrm{Z}$ & 2.15 & 2.84 & 2.34 & 0.96 & 1.96 & 1.60 \\
\hline M & 0.93 & 0.75 & 0.75 & 0.69 & 0.69 & 0.84 \\
\hline $\mathrm{F}$ & 1.22 & 2.09 & 1.59 & 0.27 & 1.27 & 0.76 \\
\hline
\end{tabular}

$Z$ = total mortality, $M=$ natural mortality, $F=$ fishing mortality; $\mathrm{Om}=$ Oreochromis mossambicus, $\mathrm{On}=$ Oreochromis niloticus . 
A

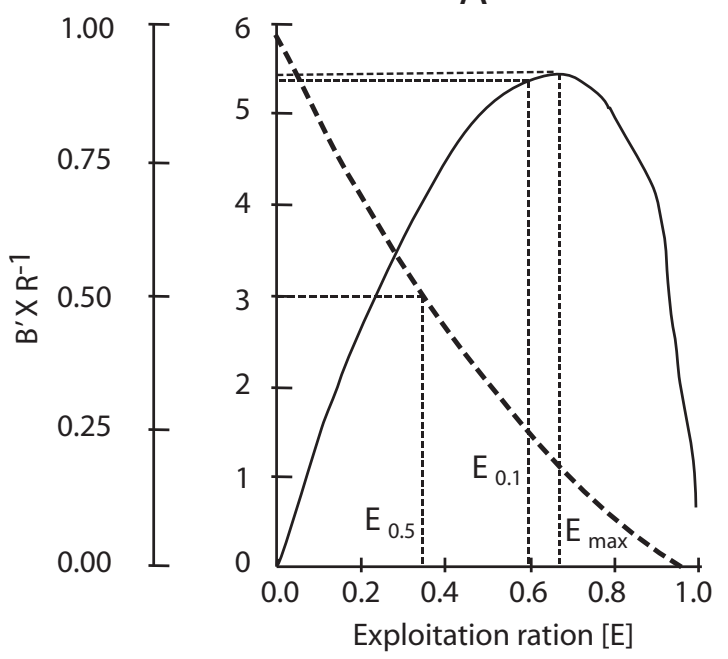

B

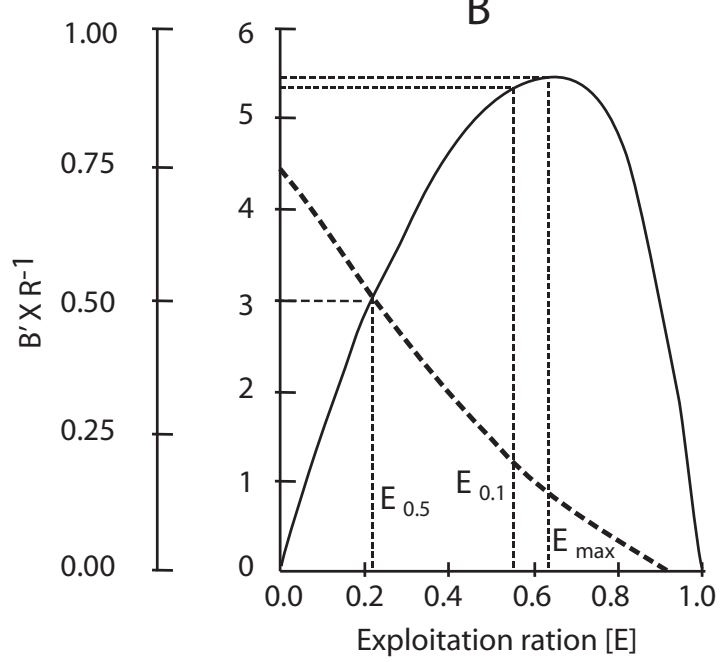

C

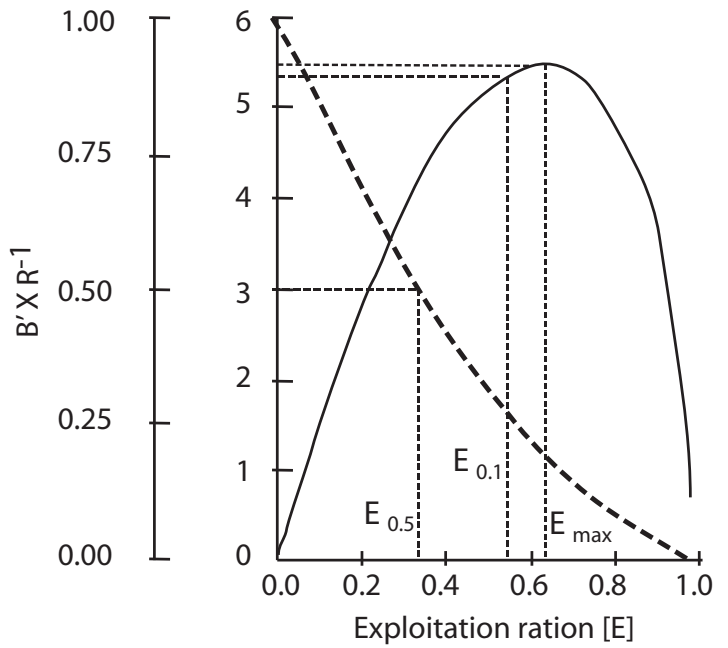

D

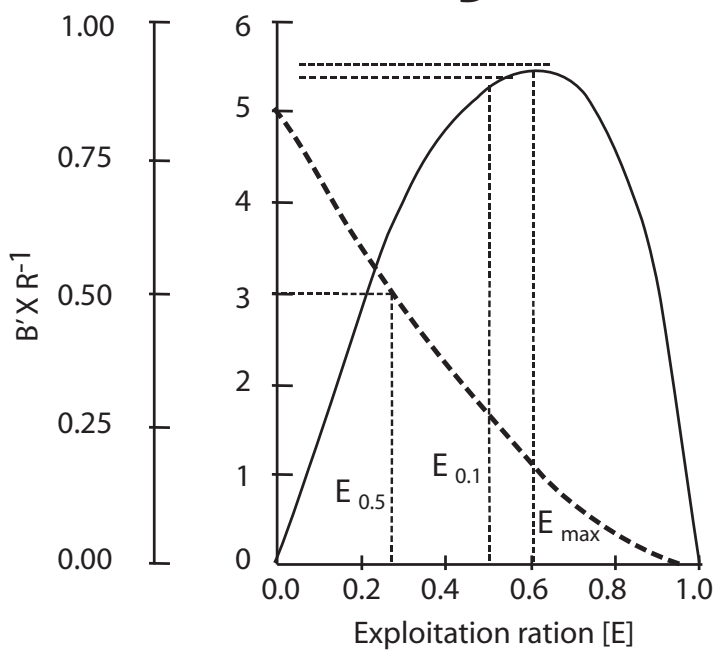

$\mathrm{E}$

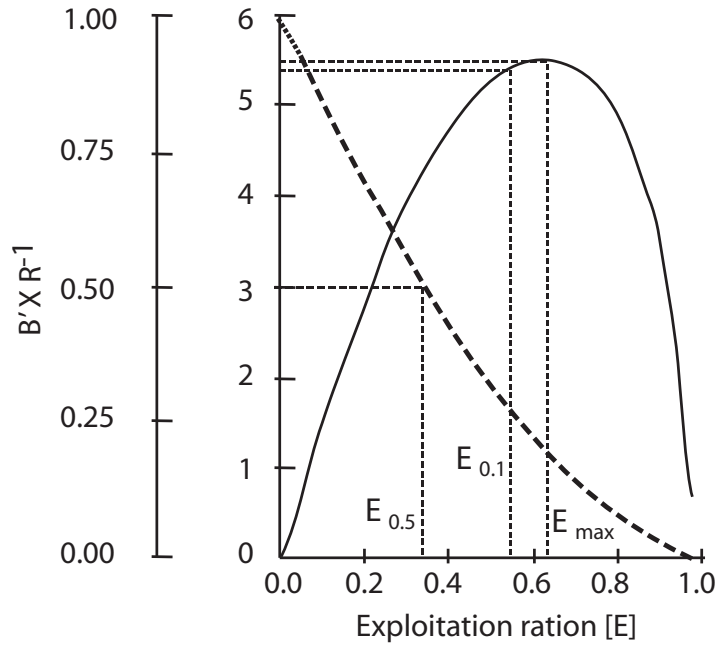

$\mathrm{F}$

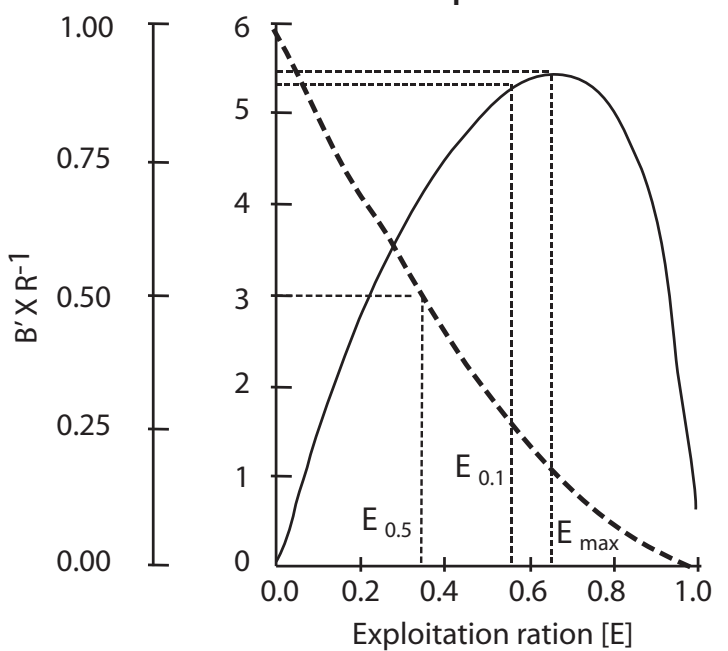

Fig. 6. Relative yield-per-recruit $\left(Y^{\prime} \times R^{-1}\right.$; solid curve) and relative biomass-per-recruit $\left(B^{\prime} \times R^{-1}\right.$; broken curve) as a function of exploitation ratio ( $E$ ) for of Oreochromis mossambicus in (A) Minneriya, (B) Udawalawe and (C) Victoria; and Oreochromis niloticus in (D) Minneriya, (E) Udawalawe and (F) Victoria; $E_{0,5}=E$ corresponding to $B^{\prime} \times R^{-1}$ of $0.5 ; E_{0.1}=E$ corresponding to $10 \%$ of slope of $Y^{\prime} \times R^{-1}$ curve at the origin; $E_{\max }=E$ corresponding to maximum $Y^{\prime} \times R^{-1}$ 
Table 5

Selected biological and exploitation parameters of Oreochromis mossambicus and Oreochromis niloticus in three reservoirs of Sri Lanka

\begin{tabular}{|c|c|c|c|c|c|c|}
\hline \multirow{3}{*}{ Parameter } & \multicolumn{6}{|c|}{ Reservoir } \\
\hline & \multicolumn{2}{|c|}{ Minneriya } & \multicolumn{2}{|c|}{ Udawalawe } & \multicolumn{2}{|c|}{ Victoria } \\
\hline & $\mathrm{Om}$ & On & $\mathrm{Om}$ & On & $\mathrm{Om}$ & On \\
\hline$L_{\mathrm{c}}[\mathrm{cm}]$ & 22.4 & 18.5 & 22.5 & 27.9 & 23.7 & 27.3 \\
\hline $\mathrm{E}$ & 0.57 & 0.74 & 0.68 & 0.28 & 0.68 & 0.48 \\
\hline$L_{\mathrm{c}-\mathrm{opt}}[\mathrm{cm}]$ & 20.0 & 20.4 & 18.7 & 21.8 & 19.0 & 20.9 \\
\hline$E_{\text {opt }}$ & 0.75 & 0.65 & 0.75 & 0.75 & 0.75 & 0.75 \\
\hline$E_{0.1}^{\text {op }}$ & 0.62 & 0.51 & 0.60 & 0.62 & 0.62 & 0.65 \\
\hline$M_{\mathrm{opt}}[\mathrm{cm}]$ & 8.8 & 8.5 & 8.1 & 9.0 & 8.3 & 8.7 \\
\hline
\end{tabular}

$L_{\mathrm{c}}=$ total length at first capture with $50 \%$ selection, $E=$ exploitation rate, $L_{\mathrm{c}-\mathrm{opt}}=$ optimal length at first capture, $E_{\mathrm{opt}}=$ optimal exploitation rate, $E_{0.1}=$ exploitation rate at which the slope of the yield per recruit curve as a function of $E$ is $10 \%$ of its value at the origin, $M_{\mathrm{opt}}=$ optimal gillnet (mesh size) corresponding to $L_{\text {c-opt }} ; \mathrm{Om}=$ Oreochromis mossambicus, $\mathrm{On}=$ Oreochromis niloticus .

using summation of probabilities of capture from all mesh sizes (Kolding 2009). In many artisanal fisheries such as the present case, mesh composition of gillnets used may vary from boat to boat making it difficult to use average selection curve. When the gillnet selection curves for different mesh sizes are computed, the overall selection pattern of a sampled boat can be determined using equation (1) above so that the length frequency data can be more accurately corrected for gillnet selection.

In length-based stock assessment using ELEFAN and similar methods, estimation of VBGF parameters, which is one of the major challenges, is effective when unbiased length frequency data are available representing curvature section of the growth curve, i.e., length frequencies which are much smaller than $L_{\infty}$ (Sparre and Venema 1998). This is particularly due to the reason that the curvature of VBGF growth curve would decrease as the fish grow older (Gulland and Rosenberg 1992). Correction for gear selection therefore has an additional advantage because corrected length frequencies for smaller size classes receive greater emphasis in the analysis, eliminating possible upward and downward biases of growth parameters (Pauly 1986).

Another breakthrough in the present analysis is that prevention of possible overestimation of $Z$ from lengthconverted catch curve method due to gear selection effect on upper range of length frequencies. Probabilities of capture determined from the $F$-array of VPA gave a clue about the size range of fish in the exploited phase of the stock which represented probability of capture close to unity.

The present analysis is essentially a follow-up study performed by Jayasinghe et al. (2017) on the determination of gillnet selectivity patterns using Baranov-Holt method (Baranov 1914, Holt 1963). This gillnet selectivity analysis was based on the assumptions that fishes of size classes are equally available to different mesh sizes, and that catchability in gillnets is dependent on the geometric shape of the fish and the mesh size (Baranov 1948). These assumptions are a useful simplification and the basis of the majority of gillnet selection studies (Hamley 1975,
Kirkwood and Walker 1986, Huse et al. 2000, Baremore et al. 2012).

Yield-per-recruit $\left(Y \times R^{-1}\right)$ models are widely used in tropical fisheries management especially due to the availability of algorithms for the purpose (Gayanilo et al. 2005), and incorporation of practical extensions to Beverton and Holt's $Y \times R^{-1}$ model (Pauly and Soriano 1986). For example, silver kob, Argyrosomus inodorus Griffiths et Heemstra, 1995 fishery in Namibian waters, based on $Y \times R^{-1}$ approaches, were recommended to be managed by introducing total allowable catch and size limits for capture (Kirchner 2001). Miranda et al. (2000) employed $Y \times R^{-1}$ models to assess the likelihood of growth and recruitment overfishing in the fisheries at Itaipu reservoir, BrazilParaguay, using selective properties of gillnet mesh sizes used. Montaño and Morales (2013) also recommended mesh size limits for Cynoscion acoupa (Lacepède, 1801) in Lake Maracaibo, Venezuela using $Y^{\prime} \times R^{-1}$ analysis. Exploitation status of major fishery target species in Lake Koka, Ethiopia, assessed by FiSAT II software, was found to be different among species and as such, the optimal levels of exploitation determined from the analysis were in conflict (Tesfaye and Wolff 2015). Novaes and Carvalho (2012) analysed length frequency data of Oreochromis niloticus population in Barra Bonita reservoir, Brazil using FiSAT software and recommended that although there was no indication of overfishing, no restrictions would need to be imposed to its fishing activities due to exotic condition of the species. Chen et al. (1998) have demonstrated that when the primary assumption in $Y \times R^{-1}$ models, i.e., randomness in the distribution of fish and effective fishing effort throughout the fishery, is not satisfied, size dependent differences in spatial distributions of fish and spatial differences in selection patterns of fishing gear should be applied. Jones and Wells (2001) employed $Y \times R^{-1}$ model to show that it is unlikely that that growth overfishing of the long-lived black drum, Pogonias chromis (Linnaeus, 1766), along the east coast of the United States. As $Y \times R^{-1}$ models are essentially single species models, the management recommendations drawn from these models for one species in a multispecies 
fishery may not necessarily be common to all species in the community (Sparre and Venema 1998).

The practical utility of the presently reported study is that this analysis is useful for drawing important management recommendations to the fisheries of two cichlid species in the three reservoirs studied. In each of the three reservoirs studied, the two cichlid species were caught in the same fleet of gillnets. As evident from the present analysis, in all three reservoirs, the gillnet mesh size corresponding to the optimal length at first capture of both species is close to the legal size of $8.5 \mathrm{~cm}$ stretched mesh according to inland fisheries regulations of Sri Lanka (Anonymous 1996). As such, regulation $L_{c}$ of two cichlid species in the fisheries of three reservoirs through mesh regulation would be possible.

In the present analysis, $E_{0.1}$ was used as the reference point for management of fisheries and as such, there would be some provision to increase exploitation rate for fishers without any serious impact on the fishery. $Y^{\prime} \times R^{-1}$ analyses predicted increase of present $E$ of Oreochromis mossambicus in Minneriya reservoir and of O. niloticus both in Udawalawe and Victoria reservoirs. Decrease of present $E$ was needed for $O$. niloticus in Minneriya and $O$. mossambicus both in Udawalawe and Victoria reservoirs. Interestingly, although both cichlid species are caught in gillnets simultaneously, $Y^{\prime} \times R^{-1}$ analyses predicted increase of $E$ for one species while its decrease for the other species. This suggests that there might be some other factors affecting $E$ of these cichlid species such as fish behaviour and their distribution patterns, and also perhaps fishers' choice of fishing areas in the reservoir. As mentioned above, some of the assumptions of $Y \times R^{-1}$ models are not satisfied in all fish populations (Chen et al. 1998).

\section{ACKNOWLEDGEMENTS}

This study was carried out as part of the EU-funded 'FISHSTRAT' project (Project No. IC 18CT 970190). We are grateful to late Dr. Annie Duncan and Professor David Simon (Royal Holloway, University of London), who have served as the coordinators of the project. Mr. P.A.D. Ajith Kumara and Dr. W.S. Weliange assisted in field data collection. We also wish to thank Messrs Krishan Rajapakse and Nuwan Gunawardena for their assistance in preparing figures.

\section{REFERENCES}

Al-Hosni A.H.S., Siddeek S.M. 1999. Growth and mortality of the narrowbarred Spanish Mackerel, Scomberomorus commerson (Lacepède), in Omani waters. Fisheries Management and Ecology 6 (2): 145-160.

DOI: $10.1046 / j .1365-2400.1999 .00134 . x$

Amarasinghe U.S. 2002. The fishery and population dynamics of Oreochromis mossambicus and Oreochromis niloticus (Osteichthyes, Cichlidae) in a shallow irrigation reservoir in Sri Lanka. Asian Fisheries Science 15 (1): 7-20.
Amarasinghe U.S., De Silva S.S. 1992. Population dynamics of Oreochromis mossambicus and O. niloticus (Cichlidae) in two reservoirs of Sri Lanka. Asian Fisheries Science 5 (1): 37-61.

Amarasinghe U.S., De Silva S.S. 2015. Fishes and fisheries of Asian inland lacustrine waters. Pp. 384-403. DOI: 10.1002/9781118394380.ch31. In: Craig J.F. (ed.) Freshwater Fisheries Ecology. John Wiley and Sons, Chichester, UK.

Amarasinghe U.S., De Silva S.S., Moreau J. 1989. Spatial changes in growth and mortality and effects on the fishery of Oreochromis mossambicus (Pisces, Cichlidae) in a man-made lake in Sri Lanka. Asian Fisheries Science 3 (1): 57-68.

Amarasinghe U.S., Weerakoon D.E.M. 2009. Present status and future strategies for the management of reservoir fisheries in Sri Lanka. Pp. 69-98. In: De Silva S.S., Amarasinghe U.S. (eds.) Status of reservoir fisheries in five Asian countries. NACA Monograph No. 2. Network of Aquaculture Centres in Asia-Pacific, Bangkok, Thailand.

Anonymous 1995. A synthesis of simple empirical models to predict fish yields in tropical lakes and reservoirs (R. 6178), Final Report. MRAG Ltd., London, UK.

Anonymous 1996. Inland fisheries management regulations of 1996. Official Gazette of Sri Lanka (Extraordinary) of 7 November, 1996, Colombo, Sri Lanka.

Athukorala D.A., Amarasinghe U.S. 2010. Population dynamics of commercially important fish species in two reservoirs of the Walawe river basin, Sri Lanka. Asian Fisheries Science 23 (1): 71-90.

Avakyan A.B., Iakovleva V.B. 1998. Status of global reservoirs: The position in the late twentieth century. Lakes and Reservoirs: Research and Management 3 (1): 45-52.

DOI: $10.1111 /$ j.1440-1770.1998.tb00031.x

Baranov F.I. 1914. Lov sel'di stavnymi setâmi. [The capture of herring with gillnets.] Materialy k poznaniû russkogo rybolovstva 3 (6): 56-69. [In Russian.]

Baranov F.I. 1948. Teoriâ i rasčet orudij rybolovstva. [Theory and assessment of fishing gear.] Piŝepromizdat, Moskva, USSR.

Baremore I.E., Bethea D.M., Andrews K.I. 2012. Gillnet selectivity for juvenile blacktip sharks (Carcharhinus limbatus). Fishery Bulletin 110 (2): 230-241.

Caddy J.F., Mahon R. 1995. Reference points for fisheries management. FAO Fisheries Technical Paper No. 347, 83 p.

Chen Y., Liggins G.W., West R.J. 1998. A yieldper-recruit model for sequential fisheries and its application in evaluating management strategy of changing incidental inshore fishing mortality. Aquatic Sciences 60 (2): 130-144. DOI: $10.1007 / \mathrm{s} 000270050030$

Cowx I.G. (ed.) 1996. Stock assessment in inland fisheries. Wiley-Blackwell, Oxford, UK.

De Silva S.S. 1988. Reservoirs of Sri Lanka and their fisheries. FAO Fisheries Technical Paper No. 298. 
De Silva S.S. 1996. The Asian inland fishery with special reference to reservoir fisheries: A reappraisal. Pp. 321332. In: Schiemer F., Boland K.T. (eds.) Perspectives in tropical limnology. SPB Academic Publishing, Amsterdam, the Netherlands.

De Silva S.S., Amarasinghe U.S. 2009. Status of reservoir fisheries in five Asian countries. NACA Monograph No. 2. Network of Aquaculture Centres in Asia-Pacific, Bangkok, Thailand.

De Silva S.S., Senaratne K.A.D.W. 1988. Oreochromis mossambicus is not universally a nuisance species: The Sri Lankan experience. Pp. 445-450. In: Pullin R.S.V., Bhukaswan T., Tonguthai K., Maclean J.L. (eds.) The Second International Symposium on Tilapia in Aquaculture. ICLARM Conference Proceedings 15, Department of Fisheries, Bangkok, Thailand, and International Centre for Living Aquatic Resources Management, Manila, the Philippines.

De Silva S.S., Moreau J., Amarasinghe U.S., Chookajorn T., Guerrero R.D. 1991. A comparative assessment of the fisheries in lacustrine inland waters in three Asian countries based on catch and effort data. Fisheries Research 11 (2): 177-189. DOI: 10.1016/0165-7836(91)90107-Q

Fernando C.H., Holčík J. 1991. Fish in reservoirs. Internationale Revue der gesamten Hydrobiologie und Hydrographie 76 (2): 149-167. DOI: 10.1002/iroh.19910760202

Fonseca P., Martins R., Campos A., Sobral P. 2005. Gill-net selectivity off the Portuguese western coast. Fisheries Research 73 (3): 323-339.

DOI: 10.1016/j.fishres.2005.01.015

Froese R., Pauly D. (eds.) 2017. FishBase. [Version 06/2017] www.fishbase.org

Gayanilo F.C.jr., Pauly D. 1997. FAO-ICLARM Stock Assessment Tools (FiSAT) reference manual. FAO Computerized Information Series (Fisheries). No. 8, FAO, Rome.

Gayanilo F.C.jr., Sparre P., Pauly D. 2005. FAOICLARM Stock Assessment Tools II (FiSAT II). Revised version. User's guide. FAO Computerized Information Series (Fisheries). No. 8, FAO, Rome.

Gray C.A., Broadhurst M.K., Johnson D.D., Young D.J. 2005. Influences of hanging ratio, fishing height, twine diameter and material of bottom-set gillnets on catches of dusky flathead Platycephalus fuscus and non-target species in New South Wales, Australia. Fisheries Science 71 (6): 1217-1228. DOI: $10.1111 / j .1444-2906.2005 .01086 . x$

Gulland J.A., Boerema L.K. 1973. Scientific advice on catch levels. Fishery Bulletin 71 (2): 325-335.

Gulland J.A., Rosenberg A.A. 1992. A review of length-based approaches to assessing fish stocks. FAO Fisheries Technical Paper No. 323, FAO, Rome.

Hamley J.M. 1975. Review of gillnet selectivity. Journal of the Fisheries Research Board of Canada 32 (11): 1943-1969.

DOI: $10.1139 /$ f75-233
Holst R., Wileman D., Madsen N. 2002. The effects of twine thickness on the size selectivity and fishing power of Baltic cod gill nets. Fisheries Research 56 (3): 303-312.

DOI: $10.1016 / \mathrm{S} 0165-7836(01) 00328-9$

Holt S.J. 1963. A method for determining gear selectivity and its application. ICNAF Special Publication 5: 106-115.

Huse I., Løkkeborg S., Soldal A.V. 2000. Relative selectivity in trawl, longline and gillnet fisheries for cod and haddock. ICES Journal of Marine Sciences 57 (4): 1271-1282. DOI: $10.1006 / j m s c .2000 .0813$

Jayasinghe R.P.P.K., Amarasinghe U.S., Moreau J. 2017. Multi-mesh gillnet selectivity of Oreochromis mossambicus and $O$. niloticus (Cichlidae) in the fishery of three large perennial reservoirs in Sri Lanka. Sri Lanka Journal of Aquatic Sciences 22 (1): 55-66. DOI: $10.4038 /$ sljas.v22i1.7517

Jones C.M., Wells B.K. 2001. Yield-per-recruit analysis for black drum, Pogonias cromis, along the east coast of the United States and management strategies for Chesapeake Bay. Fishery Bulletin 99 (2): 328-337.

Kirchner C.H. 2001. Fisheries regulations based on yield-per-recruit analyses for the linefish silver kob Argyrosomus inodorus in Namibian waters. Fisheries Research 52 (3): 155-167. DOI: $10.1016 / \mathrm{S} 0165-7836(00) 00258-7$

Kirkwood G.P., Walker T.I. 1986. Gillnet mesh selectivities for gummy shark, Mustelus antarcticus Günther, taken in south-eastern Australian waters. Australian Journal of Marine and Freshwater Research 37 (6): 689-697.

DOI: $10.1071 /$ MF9860689

Kolding J. 2009. Introduction and Manual to Pasgear 2, Version 2.3 (Build 2.12.2009), Jeppe Kolding and Åsmund Skålevik. University of Bergen, Bergen, Norway.

Kosai P., Sathavorasmith P., Jiraungkoorskul K., Jiraungkootskul W. 2014. Morphometric characters of Nile tilapia (Oreochromis niloticus) in Thailand. Walaialak Journal of Science and Technology 11 (10): 857-863.

DOI: 10.14456/WJST.2014.76

Miranda L.E., Agostinho A.A., Gomes L.G. 2000. Appraisal of the selective properties of gill nets and implications for yield and value of fisheries at the Itaipu Reservoir, Brazil-Paraguay. Fisheries Research 45 (2): 105-116.

DOI: 10.1016/S0165-7836(99)00114-9

Montaño O.J.F., Morales I.C. 2013 Relative yield-perrecruit and management strategies for Cynoscion acoupa (Perciformes: Sciaenidae) in Lake Maracaibo, Venezuela. Revista de Biología Tropical 61 (1): 173180.

Moreau J., Bambino C., Pauly D. 1986. Indices of overall growth performance of 100 tilapia (Cichlidae) population. Pp. 201-206. In: Maclean J., Dizon L.B., 
Hosillos L.V. (eds.) The First Asian Fisheries Forum. Asian Fisheries Society, Manila, the Philippines.

Moreau J., Amarasinghe U.S., Sricharoendham B., Jayasinghe R.P.P.K., Villanueva M.C. 2008. Population dynamics of commercially important fish species in four Asian reservoirs. Pp. 295-304. In: Schiemer F., Simon D., Amarasinghe U.S., Moreau. J. (eds.) Aquatic ecosystem and development: Comparative Asian perspectives. Biology of inland waters. Backhuys Publishers, Leiden, the Netherlands.

Novaes J.L.C., Carvalho E.D. 2012. Reproduction, food dynamics and exploitation level of Oreochromis niloticus (Perciformes: Cichlidae) from artisanal fisheries in Barra Bonita Reservoir, Brazil. Revista de Biología Tropical 60 (2): 721-734.

DOI: $10.15517 /$ rbt.v60i2.3987

Oglesby R.T. 1985. Management of lacustrine fisheries in the tropics. Fisheries 10 (2): 16-19. DOI: 10.1577/1548-8446(1985)010<0016:MOLFIT >2.0.CO;2

Pauly D. 1980. On the interrelationships between natural mortality, growth parameters, and mean environmental temperature in 175 fish stocks. Journal du Conseil. Conseil Permanent International pour l'Exploration de la Mer 39 (2): 175-199.

DOI: 10.1093/icesjms/39.2.175

Pauly D. 1983. Length-converted catch curves: A powerful tool for fisheries research in the tropics (Part I). Fishbyte 1 (2): 9-13.

Pauly D. 1984. Recent developments in the methodology available for the stock assessment of reservoirs. Pp. 321-326. In: Kapetsky J.M., Petr T. (eds.), Status of African reservoir fisheries. CIFA Technical Paper No. 10. FAO, Rome.

Pauly D. 1986. On improving operation and use of the ELEFAN programs. Part III. Correcting lengthfrequency data for the effect of gear selection and/or incomplete recruitment. Fishbyte 4 (2): 11-13.

Pauly D. 1998. Tropical fishes: Patterns and propensities. Journal of Fish Biology 53 (Suppl. A), 1-17. DOI: 10.1111/j.1095-8649.1998.tb01014.x

Pauly D., Morgan G.R. 1987. Length-based Methods in Fisheries Research. International Centre for Living Aquatic Resources Management, Manila, the Philippines.
Pauly D., Munro J.L. 1984. Once more on the comparison of growth in fish and invertebrates. Fishbyte 2 (1): 21.

Pauly D., Soriano M.L. 1986. Some practical extensions to Beverton and Holt's relative yield-per-recruit model. Pp. 491-496. In: Maclean J.L., Dizon L.B., Hosillo L.V. (eds.) The First Asian Fisheries Forum. Asian Fisheries Society, Manila, the Philippines.

Pet J.S., Wijsman J.W.M., Mous P.J., Machiels M.A.M. 1995. Characteristics of a Sri Lankan reservoir fishery and consequences for the estimation of annual yield. Fisheries Research 24 (1): 9-33. DOI: 10.1016/0165-7836(94)00360-9

Rudstam L.G., Magnuson J.M., Tonn W.L. 1984. Size selectivity of passive fishing gear: A correction for encounter probability applied to gill nets. Canadian Journal of Fisheries and Aquatic Sciences 41 (8): 1252-1255.

DOI: $10.1139 /$ f84-151

Silva E.I.L., Gamlath G.A.R.K. 2000. Catchment characteristics and water quality of three reservoirs (Victoria, Minneriya and Udawalawe) in Sri Lanka. Sri Lanka Journal of Aquatic Sciences 5 (1): 55-75.

Sparre P., Venema S.C. 1998. Introduction to tropical fish stock assessment. Part 1. Manual. FAO Fisheries Technical Paper No. 306.1: Rev. 2. FAO, Rome.

Sricharoendham B., Amarasinghe U.S., Jayasinghe R.P.P.K., Aypa S.M. 2008. Status of the capture fisheries in four Asian reservoirs and a volcanic lake. Pp. 265-284. In: Schiemer F., Simon D., Amarasinghe U.S., Moreau J. (eds.) Aquatic ecosystem and development: Comparative Asian perspectives. Biology of inland waters, Backhuys Publishers, Leiden, the Netherlands.

Tesfaye G., Wolff M. 2015. Stock assessment of fishery target species in Lake Koka, Ethiopia. Revista de Biología Tropical 63 (3): 755-770.

Tweddle D., Bodington P. 1988. A comparison of the effectiveness of black and white gillnets in Lake Malawi, Africa. Fisheries Research 6 (3): 257-269. DOI: 10.1016/0165-7836(88)90018-5

Welcomme R.L. 2001. Inland fisheries: Ecology and management. FAO Rome and Fishing News Books, Blackwell Science, Oxford, UK. DOI: 10.1002/9780470995693

Received: 23 December 2016

Accepted: 30 July 2017 Published electronically: 30 September 2017 